\title{
PENGGUNAAN MEDIA PEMBELAJARAN BIOLOGI DI SEKOLAH MENENGAH ATAS (SMA) SWASTA SALATIGA
}

\author{
Agus Ariyanto ${ }^{1}$ \\ Desy Fajar Priyayi ${ }^{2}$ \\ Lusia wati Dewi $^{3}$ \\ 1,2,3) Universitas Kristen Satya Wacana \\ E-mail: ariyantoagus135@g mail.com
}

\begin{abstract}
Learning media is a tool to improve teaching and leaming process to achieve better leaming outcome. This research is a qualitative descriptive study. The purpose of this research was 1) to know the types of biology learning media found in senior high school at Salatiga,2) to analyze the application of media in the process of biology learning in senior high school at Salatiga, 3) to know the factors that influence the use of learning media in private senior high school at Salatiga. Techniques and data collection tools were questionnaires, interviews, observation, and documentation. Data were obtained from biology teachers and high school students in Salatiga. Data analysis techniques include the stages of data collection, data reduction, data presentation, and conclusions. Based on the result of research, it can be concluded that the complete type of learning media is learning media contained in school B, ie print media, visual, audio-visual, realia, game, electronic or computer. The highest of media type used by biology teacher printed media. According to the teacher, subjects that most need learning media are biotechnology, metabolism, plant growth, genetic material, heredity of Mendel, evolution, the origin of life, cell reproduction. Factors that influence media using were material difficulty level, media availability level, level of preparedness of student, time and number of students.
\end{abstract}

Kata kunci: media pembelajaran biologi, sekolah menengah atas

Pembelajaran merupakan proses yang melibatkan berbagai komponen yang saling berhubungan. Komponen di dalamnya antara lain berupa tujuan pembelajaran, materi pembelajaran, strategi dan metode pembelajaran, media pembelajaran, pengorganisasian kelas, evaluasi pembelajaran, dan tindak lanjut pembelajaran.Media pembelajaran menjadi salah satu komponen yang penting untuk mendukung proses pembelajaran di kelas. Media pembelajaran didefinisikan sebagai alat bantu yang digunakan untuk menyalurkan pesan dalam proses pembelajaran sehingga dapat merangsang pikiran, perasaan, perhatian, dan minat belajar siswa sehingga tujuan pembelajaran dapat tercapai (Basri dkk., 2013 : 38., Naz dkk., 2012:39). Menguraikan manfaat dari media pembelajaran antara lain: 1) memperjelas penyajian pesan dan informasi sehingga dapat meningkatkan proses dan hasil belajar, 2) meningkatkan perhatian siswa sehingga dapat menimbulkan motivasi belajar, 3) mengatasi keterbatasan indera, ruang, dan waktu, 4) memberikan kesamaan pengalaman kepada siswa berkaitan dengan peristiwa yang ada di lingkungan (Kustandi dan Sutjipto. 2011:23). 


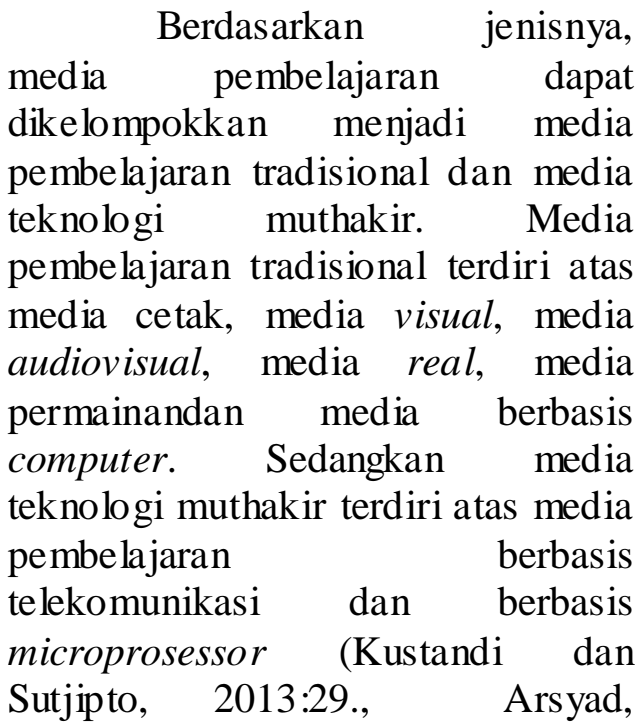
2002:33). Sesuai perkembangan zaman dan kebutuhan siswa, inovasi berbagai media pembelajaran terus dilakukan guna mendukung proses pembelajaran. Hal ini berlaku pada semua bidang mata pelajaran, termasuk biologi.

Biologi merupakan bagian dari ilmu sains yang mempelajari makhluk hidup berdasarkan tingkat organisasi termasuk interaksinya dengan lingkungan. Produk keilmuan biologi berwujud kumpulan fakta dan konsep (Sudjoko, 2001: 2). Tidak semua konsep dalam biologi bersifat konkret dan mudah diamati. Sebaliknya terdapat konsep yang bersifat abstrak dan tidak mudah diamati.

Hasil observasi berkaitan dengan masalah dalam proses pembelajaran biologi di Salatiga dan kabupaten Semarang menunjukkan bahwa $80,61 \%$ guru menganggap masalah dalam pembelajaran adalah berkaitan dengan masalah siswa meliputi kecenderungan siswa untuk diam dan malu untuk bertanya, motivasi siswa kurang, ditunjukkan dari siswa kurang antusias, siswa malas mengerjakan tugas, siswa mengantuk, siswa gaduh dan tidak konsentrasi. Akibatnya tentu berdampak pada rendahnya hasil belajar biologi. Selain itu, keterbatasan media pembelajaran menjadi masalah pembelajaran kedua terbesar yang dialami oleh guru. Padahal sesuai dengan fungsinya, penggunaan media pembelajaran akan memudahkan siswa dalam mempelajari konsep dalam biologi dan dapat meningkatkan motivasi dan hasil belajar biologi (Basri, 2013:37., Yudasmara dan Purnami, 2015: 6). Namun belum diketahui media-media pembelajaran yang dimiliki oleh sekolah dan digunakan oleh guru biologi, khususnya di Salatiga. SMA A, SMA B dan SMA C. Ketiga sekolah tersebut merupakan sekolah swasta terakreditasi A di Salatiga. Sekolah swasta dipilih menjadi tempat penelitian karena sekolah swasta menggunakan dana sendiri untuk membeli sarana prasarana misalnya media pembelajaran untuk menunjang proses belajar mengajar. Oleh karena itu, penting untuk menganalisis lebih dalam berkaitan dengan media pembelajaran apa saja yang telah digunakan guru biologi di sekolah termasuk faktor-faktor yang mempengaruhi penggunaannya.

\section{METODE}

\section{Tempat Penelitian}

Penelitian ini dilakukan di Sekolah Menengah Atas (SMA) Swasta di Salatiga, meliputi 3 SMA yaitu SMA A, SMA B, SMA C.

\section{Subyek Penelitian}

Subyek dalam penelitian ini adalah guru-guru biologi di tiga SMA swasta di Salatiga dan siswa ipa ( kelas X IPA, XI IPA, XII IPA) Sekolah yang menjadi subyek antara lain yaitu SMA A, SMA B dan SMA C. 


\section{Teknik dan Instrumen Pengumpulan Data \\ 3.1. Angket}

Peneliti memberikan sejumlah pertanyaan atau pernyataan kepada guru dan siswa untuk dijawab. Instrumen angket dikembangkan berdasarkan aspek-aspek media pembelajaran yang akan dianalisis. Jenis pertanyaan berupa pertanyaan terbuka dan tertutup.

\subsection{Wawancara}

Wawancara dilakukan dengan memberikan seperangkat pertanyaan secara lisan kepada responden yaitu guru dan siswa. Intrumen yang digunakan adalah lembar wawancara. Wawancara bermanfaat untuk mengetahui informasi yang belum tersampaikan pada instrument tertulis. Jenis wawancara yang dilakukan adalah wawancara tidak terstruktur.

\subsection{Observasi dan dokumentasi}

Observasi dilakukan untuk mengetahui jenis dan kondisi media pembelajaran yang dimiliki oleh sekolah. Instrumen yang digunakan berupa lembar observasi.

\section{Teknik Analisis Data}

Penelitian ini merupakan penelitian deskriptif kualitatif dengan tahapan analisis meliputi : tahap pengumpulan data, reduksi data, penyajian data, dan penarikan kesimpulan (Sugiyono, 2014 : 338).

4.1 Pengumpulan data

Tahap pengumpulan data adalah tahap pengumpulan data dengan menggunakan instrument yang telah disiapkan.

\subsection{Reduksi data}

Reduksi data dapat diartikan sebagai proses penentuan, pemusatan perhatian dalam penyederhanaan, pengabstrakan serta transformasi data kasar yang timbul berasal dari catatan-catatan tertulis di lapangan. Reduksi data terjadi secara terus-menerus saat penelitian dilaksanakan. Reduksi data merupakan tahap analisis yan pada saat peneliti menajamkan, menggolongkan, mengarahkan, menyingkirkan yang tidak berguna serta mengorganisasi data menggunakan cara sedemikian rupa yang menyebabkan ditariknya kesimpulan.

4.3.Penyajian data

Tahap penyajian data berguna untuk menghindari kesulitan pada waktu melaksanakan penarikan kesimpulan sehingga data yang sudah terkumpul memerlukan penyajian dalam bentuk-bentuk sedemikian rupa yang berguna menggabungkan informasiinformasi yang sudah didapatkan. Inti serta kegiatan ini yaitu mengorganisir informasi dengan sistematis yang berguna dalam mempermudah peneliti saat menggabungkan serta merangkaikan keterikatan antar data yang terkait dengan fenomena yang terjadidi dalam proyek penelitian.

\subsection{Penarikan kesimpulan}

Penarikan kesimpulan dapat diambil dari wawancara guru dan atau peserta didik, angket, observasi dan dokumentasi media pembelajaran yang dimiliki oleh sekolah.

\section{Analisis Data}

Penelitian ini merupakan penelitian deskriptif kualitatif. Penelitian deskriptif kualitatif adalah penelitian yang menggambarkan secara urut, faktual serta akurat tentang fakta-fakta, karakteristik dan keterkaitan mengenai suatu kejadaian dengan kejadain yang lain dalam observasi dan pencarian 
penyelidikan, dengan tidak menggunakan perhitungan maupun memproses data statistik lebih lanjut. (Indraswari, $2005: 20$ ).

\section{HASIL}

Tabel 1. Data definisi media pembelajaran oleh guru Biologi SMA A, B dan C

\begin{tabular}{|c|c|c|}
\hline No & Guru & Definisi \\
\hline 1 & A1 & $\begin{array}{l}\text { Sarana untuk mengajar siswa } \\
\text { di dalam menunjang } \\
\text { terjadinya proses belajar } \\
\text { mengajar yang menarik buat } \\
\text { siswa. }\end{array}$ \\
\hline & B1 & $\begin{array}{lr}\begin{array}{l}\text { Suatu media atau alat yang } \\
\text { digunakan }\end{array} & \text { dalam } \\
\text { pembelajaran } & \text { untuk } \\
\text { membantu } & \text { meningkatkan } \\
\text { pemahaman } & \text { suatu materi } \\
\text { tertentu secara konkrit. }\end{array}$ \\
\hline 2 & B2 & $\begin{array}{l}\text { Sarana berupa alat atau } \\
\text { perangkat yang berfungsi } \\
\text { untuk membantu bagi siswa } \\
\text { untuk atau agar lebih mudah } \\
\text { memahami materi } \\
\text { pembelajaran sesuai tujuan } \\
\text { atau kompetensi yang akan } \\
\text { dicapai. }\end{array}$ \\
\hline \multirow{3}{*}{3} & C1 & $\begin{array}{l}\text { Alat atau sarana yang } \\
\text { dipakai untuk mendukung } \\
\text { pembelajaran. }\end{array}$ \\
\hline & $\mathrm{C} 2$ & $\begin{array}{l}\text { Suatu metode atau alat bantu } \\
\text { yang dipakai guru untuk } \\
\text { mempermudah penyampaian } \\
\text { materi, sehingga siswa lebih } \\
\text { mengerti atau memahami } \\
\text { materi. }\end{array}$ \\
\hline & C3 & $\begin{array}{l}\text { Segala sarana yang dapat } \\
\text { dipergunakan } \\
\text { mendukung proses belajar } \\
\text { mengajar, sehingga kualitas } \\
\text { pembelajaran dapat diukur } \\
\text { dengan tingkat pencapaian } \\
\text { indikator dapat tercapai. }\end{array}$ \\
\hline
\end{tabular}

Tabel 2. Datajenis media pembelajaran yang dipergunakan di beberapa SMA di Salatiga

\begin{tabular}{|c|l|c|}
\hline No & \multicolumn{1}{|c|}{ Media } & Contoh \\
\hline \multirow{3}{*}{} & Cetak & - \\
\cline { 2 - 3 } & $\begin{array}{l}\text { Visual diam } \\
\text { yang } \\
\text { diproyeksikan }\end{array}$ & - \\
\cline { 2 - 3 } $\mathbf{1}$ & Visual yang & Gambar. \\
\hline
\end{tabular}

\begin{tabular}{|c|c|c|}
\hline No & Media & Contoh \\
\hline & $\begin{array}{l}\text { tidak } \\
\text { diproyeksikan }\end{array}$ & \\
\hline & Audio visual & - \\
\hline & Realia & $\begin{array}{l}\text { Specimen } \\
\text { arthropoda. }\end{array}$ \\
\hline & Permainan & $\begin{array}{l}\text { Kertas berwarna } \\
\text { struktur kimia double } \\
\text { helix DNA. }\end{array}$ \\
\hline & $\begin{array}{l}\text { Teknologi } \\
\text { mutakhir }\end{array}$ & - \\
\hline \multirow{7}{*}{2} & Cetak & Buku teks. \\
\hline & $\begin{array}{l}\text { Visual diam } \\
\text { yang } \\
\text { diproyeksikan }\end{array}$ & $\begin{array}{l}\text { Slide materi, gambar } \\
\text { slide proyektor. }\end{array}$ \\
\hline & $\begin{array}{l}\text { Visual yang } \\
\text { tidak } \\
\text { diproyeksikan }\end{array}$ & $\begin{array}{l}\text { Charta sistem } \\
\text { pencernaan, respirasi, } \\
\text { ekskresi alat indera, } \\
\text { jaringan } \\
\text { tumbuhan,kartu } \\
\text { gambar, diagram. }\end{array}$ \\
\hline & Audio visual & $\begin{array}{l}\text { Video pembelajaran } \\
\text { materi biologi, film } \\
\text { documenter. }\end{array}$ \\
\hline & Realia & $\begin{array}{l}\text { Kebun } \begin{array}{r}\text { sekolah, } \\
\text { akuarium ekosistem }\end{array} \\
\text { air tawar, ko lam ikan, } \\
\text { insektarium, } \\
\begin{array}{l}\text { herbarium, awetan } \\
\text { biota, } \\
\text { mikroskop elektronik. }\end{array}\end{array}$ \\
\hline & Permainan & $\begin{array}{lr}\text { Kancing } & \text { genetika, } \\
\text { puzzle, baling-baling } \\
\text { genetik, } \\
\text { genetika. }\end{array}$ \\
\hline & $\begin{array}{l}\text { Teknologi } \\
\text { mutakhir }\end{array}$ & CD interaktif. \\
\hline \multirow{7}{*}{3} & Cetak & $\begin{array}{l}\text { Buku teks bacaan } \\
\text { modul, LKS. }\end{array}$ \\
\hline & $\begin{array}{l}\text { Visual diam } \\
\text { diproyeksikan } \\
\end{array}$ & $\begin{array}{l}\text { Gambar internet, } \\
\text { slide materi. }\end{array}$ \\
\hline & $\begin{array}{l}\text { Visual yang } \\
\text { tidak } \\
\text { diproyeksikan } \\
\end{array}$ & $\begin{array}{ll}\text { Charta } & \text { faktor } \\
\text { pertumbuhan. } & \end{array}$ \\
\hline & Audio visual & $\begin{array}{l}\text { Video dari internet } \\
\text { terkait kasus mutasi, } \\
\text { glikolisis, siklus kreb, } \\
\text { reaksi terang, reaksi } \\
\text { gelap, animasi } \\
\text { pembelajaran sel, } \\
\text { respirasi. }\end{array}$ \\
\hline & Realia & Preparat, torso. \\
\hline & Permainan & $\begin{array}{l}\text { TTS, kuis, video } \\
\text { simulasi. }\end{array}$ \\
\hline & $\begin{array}{l}\text { Teknologi } \\
\text { mutakhir }\end{array}$ & $\begin{array}{l}\text { Soal interakt if } \\
\text { respirasi sel. }\end{array}$ \\
\hline
\end{tabular}


Tabel 3. Data faktor yang mempengaruhi penggunaan media pembelajaran oleh guru biologi di beberapa Sekolah Menengah Atas Salatiga

\begin{tabular}{|c|c|l|}
\hline No & Guru & \multicolumn{1}{|c|}{ Faktor } \\
\hline 1 & A 1 & Waktu pelaksanaan KBM. \\
\hline \multirow{4}{*}{2} & B 1 & Tingkat kesulitan materi. \\
\cline { 2 - 4 } & \multirow{2}{*}{ B 2 } & $\begin{array}{l}\text { Kesiapan dalam PBM, } \\
\text { sarana-prasarana sekolah, } \\
\text { minat siswa, KD / materi } \\
\text { PBM, tingkat kesulitan } \\
\text { materi. }\end{array}$ \\
\hline \multirow{3}{*}{3} & C 1 & $\begin{array}{l}\text { Ketersediaan } \\
\text { penunjang di sekolah. }\end{array}$ \\
\cline { 2 - 3 } & C 2 & Kesiapan siswa. \\
\cline { 2 - 4 } & C 3 & Tingkat kesulitan materi. \\
\hline
\end{tabular}

\section{PEMBAHASAN}

\section{Jenis-jenis media pembelajaran biologi yang terdapat di SMA Salatiga}

Media pembelajaran adalah suatu alat untuk meningkatkan proses belajar mengajar untuk mencapai tujuan pembelajaran supaya lebih baik (Kustandi dan Sutjipto, 2011 : 8).Guru biologi SMA A, B dan C sebagian besar sudah memahami mengenai definisi media, tetapi yang perlu diperhatikan adalah pemilihan media dalam KBM. Media tidak bisa ditinggalkan dari kegiatan belajar mengajar untuk tercapainya tujuan pendidikan pada umumnya serta tujuan pembelajaran sekolah pada khususnya (Arsyad, 2002 : 2). Pembelajaran efektif membutuhkan perencanaan yang termasuk dalam pemilihan media pembelajaran yang digunakan. Guru berpendapat bahwa pembelajaran yang menggunakan media dapat memberikan gambaran materi yang lebih lebih baik dibandingkan hanya dengan menjelaskan saja. Hal yang perlu diperlukan dalam pemakaian media pembelajaran adalah kesesuaian media dengan tujuan pembelajaran, karena pemilihan media yang tidak sesuai justru dapat menghambat tercapainya tujuan pembelajaran. Tujuan pembelajaran bisa tercapai salah satunya menggunakan media interaktif, penggunaan media pembelajaran sering dihubungkan dengan pencapaian hasil belajar atau perkembangan siswa dalam memahami materi pelajaran (Kirkorian, dkk. (2008 : 53). Banyak penelitian yang setuju apabila media pembelajaran dapat meningkatkan pemahaman siswa maupun hasil belajar (Tabor and Robert 2013 : 203).

Peran media antara lain: 1) melancarkan informasi dan pesan sehingga berdampak kepada peningkatan hasil belajar,2) memunculkan motivasi belajardengan meningkatan, 3) mengarahkan perhatian siswa,dan 4) memberikan solusi karena terbatasnya indera, ruang serta waktu. Sedangkan fungsi media pembelajaran yaitu : 1) memberikan kemudahan siswa dalam belajar, 2) mengubah pengalaman abstrak menjadi konkret, 3) proses belajar mengajar tidak membosankan, 4) meningkatkan minat, perhatian siswa pada proses belajar (Umar 2013 : 133).

Media pembelajaran dikelompokan menjadi 2 kategori yaitu media tradisional dan media teknologi muthakir.Yang meliputi media tradisional diantaranya Visual diam yang diproyeksikan, antara lain berupa: media proyeksi overhead, slides. Kemuidan Visual yang tidak diproyeksikan, antara lain: gambar, poster, foto, grafik, diagram, papan info. Selanjutnya Audio, antara lain: rekaman, kaset. Kemudian cetak, antara lain: buku teks, modul, majalah, handout. Lalu permainan, antara lain: teka teki, simulasi, 
permainan papan. dan realia, antara lain: model, specimen, peta. Sedangkan yang meliputi media teknologi mutakhir antara lain Media berbas is telekomunikasi, yang berupa teleconference, pembelajaran jarak jauh.Kemudian media berbasis microprossesor, antara lain: interactive video, permainan computer, computer assisted instruction (Arsyad, 2011 : 33).

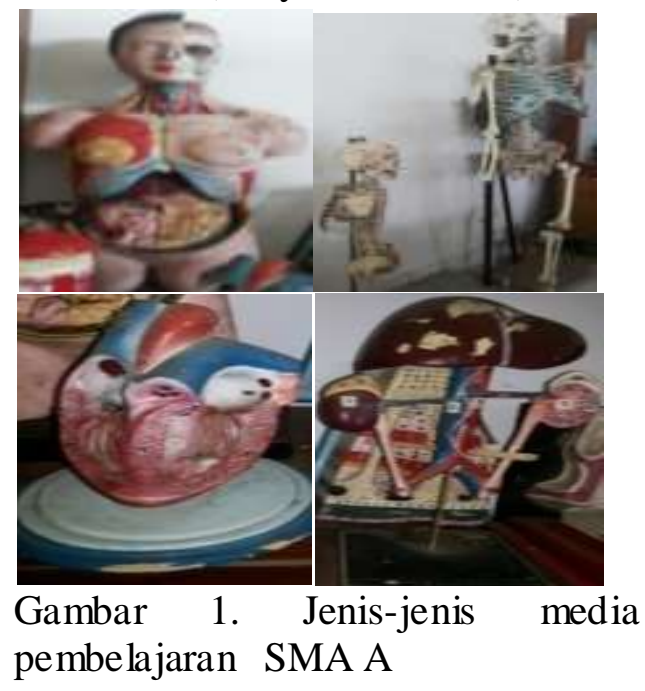

Pemakaian media pembelajaran di kelas adalah kebutuhan yang tidak bisa diabaikan, mutu guru bisa ditentukan dari kreativitas guru dalam mengembangkan media, media bisa meningkatkan proses belajar di kelas, dengan tujuan juga dapat mempertinggi hasil belajar sesuai tujuan yang diharapkan (Umar, 2013 : 134). Hasil observasi media berdasarkan jenis media menunjukkan sekolah yang memiliki media pembelajaran biologi paling banyak adalah sekolah $\mathrm{B}$ dengan jenis media berupa media cetak, visual, audio visual, realia, permainan, elektronik atau computer. Media yang terdapat di sekolah A meliputi media cetak, visual, realia, permainan.Sedangkan media pembelajaran di sekolah $\mathrm{C}$ meliputi media cetak, visual, audio visual, realia, permainan, elektronik atau computer.

Dari segi jumlah dan kualitas, media paling banyak di sekolah B adalah media real yaitu awetan basah sejumlah 16 dan awetan kering sejumlah 5 dengan kualitas baik. Sedangkan di SMA A adalah media real yaitu model alat peraga sejumlah 8 dengan kualitas baik dan SMA C berupa media real yaitu model organ manusia sejumlah 22 dengan kualitas baik dan media visual yang tidak diproyeksikan yaitu gambar sejumlah 45 dengan kuaitas baik.

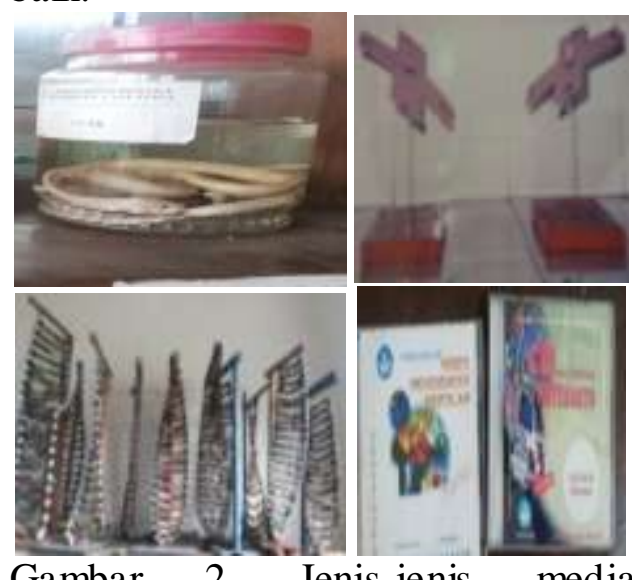

Gambar 2. Jenis-jenis media pembelajaran SMA B

SMA A memiliki jenis media pembelajaran media real yang dikelompokan sebagai berikut : Model tubuh manusia, model struktur otak dalam tengkorak, model struktur jantung, model struktur ginjal, model jaringan tumbuhan, model struktur telinga manusia dan torso. Selanjutnya SMA B jenis media pembelajarannya yaitu dkelompokan sebagai berikut, media realia : awetan basah organ dalam kelinci (Oryctolagus cuniculus), animalia cumi-cumi (Loligo sp.), awetan basah biota laut, awetan basah animalia (ular), animalia Bunglon (B. jubata), awetan basah plantae, awetan kerang, awetan biota 
laut, model tubuh manusia, torso, insektarium, model struktur sistem pendengaran, model struktur mata, struktur telinga, model replikasi DNA. Media permainan : balingbaling genetik, kancing genetika, kartu genetika. Media Visual yang tidak diproyeksikan : charta otot manusia, charta sistem pernafasan, gambar kupu-kupu, sistem pencernaan manusia, struktur ginjal. Media visual diam yang diproyeksikan : slides. Media berbasis microprossesor : CD multimedia Interaktif, progam video pendidikan sekolah. SMA C jenis media pembelajarannya yaitu dkelompokan sebagai berikut, media real : model struktur ginjal, (mould \& cosil jejak fosil Brachiopoda), Gigi dan rahang anjing hutan, (Mould \& Cast Jejak Fosil Bivalvia), model struktur kulit manusia, model struktur gigi manusia, model paruparu, model struktur telinga manusia, model struktur mata, model struktur telinga manusia, model struktur otak dalam tengkorak, model gigi, model kepala otak, model jantung, model tubuh manusia, model virus, model struktur gigi, awetan taksidermi, awetan tulang. Media Visual yang tidak diproyeksikan : gambar $3 \mathrm{D}$ system pencernaan, gambar $3 \mathrm{D}$ organ tubuh manusia, gambar $3 \mathrm{D}$ Sistem pernafasan, gambar $3 \mathrm{D}$ Peredaran darah, gambar 3 D struktur mulut manusia, gambar kupu-kupu, siklus hidup cacing pita babi, Abdomp And Thoracic Viscera. Media visual diam yang diproyeksikan : slides.

Semua guru biologi di sekolah tempat penelitian ini menyatakan,pemakaian mediapembelajaran dapat membantu guru dalam menyampaikan materi sehingga siswa lebih mudah dalam memahami mater. Pemakaian media tepat dan baik saat PBM mempunyai keuntungan bagi guru dan siswa salah satunya membantu kelancaran PBM dan bermanfaat untuk siswa dalam meningkatkan pengenalan, pemahaman terhadap materi (Emda, 2011: 161).

Guru biologi di SMA A,B, maupun $\mathrm{C}$ telah mengembangkan media pembelajaran secara mandiri. Guru biologi SMA A menyatakan jenis media pembelajaran yang telah dikembangkan yaitu model struktur kimia DNA. Guru biologi SMA B mengembangkan media yaitu model struktur DNA, kartu genetika, balingbaling genetika, peta selisih, cakram genetika, seleksi alam serta menggunakan media pembelajaran dari lingkungan langsung yang diterapkan menjadi suatu konsep pembelajaran. Kemudian guru biologi SMA C mengembangkan jenis media pembelajaran diantaranya media elektronik, kemudian media real, lalu charta, PPT, media interaktif, model organ tubuh. Hal yang perlu dipertimbangkan dalam mengembangkan media adalah kemudahan guru dan siswa dalammemanfaatkan media tersebut (Umar, 2013 : 139).

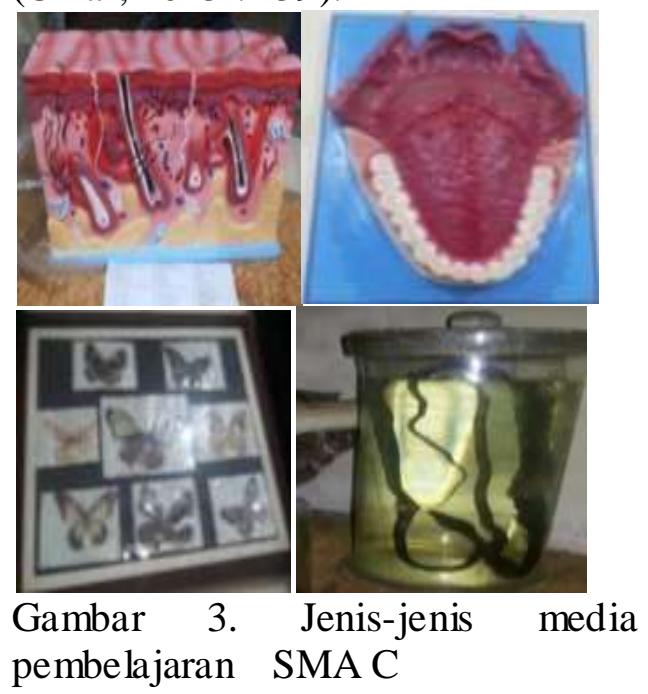


2. Penerapan media dalam proses pembelajaran biologi di Sekolah Menengah Atas Salatiga

Adanya media mempermudah guru menyajikan materi ajarnya, dan juga memberikan nilai tambah di kegiatan pembelajaran yang dilaksanakan (Kustandi dan Sutjipto 2011 : 2). Namun pada prakteknya, tidak semua guru memanfaatkan media pembelajaran secara maksimal. Hasil pengisian angket secara keseluruhan sebanyak $73.3 \%$ siswa menyatakan guru biologi sering menggunakan alat bantu atau media pembelajaran dalam proses belajar mengajar. Sebanyak $77.5 \%$, siswacepat bosan jika mengikuti pembelajaran hanya mencatat serta mendengarkan saja tanpa menggunakan media pembelajaran. Pemakaian media pembelajaran dapat mengatasi kelelahan dan kebosanan siswa (Dzamarah dan Zain 2006: 137).Sebanyak $64.8 \%$ siswa juga menyatakan materi pelajaran yang menggunakan media pembelajaran memberikan pengalaman mengesankan. Siswa harus diberi pengalaman yang menyenangkan sesuai kebutuhan lewat adanya media pembelajaran(Kustandi dan Sutjipto, 2011: 19). Hasil belajar siswa bisa mengalami kenaikan jika menggunakan media pembelajaran, hal ini sudah dibuktkan oleh guru B2 di SMA B dalam penelitian tindakan kelas (PTK).

Belum semua guru biologi di tempat penelitian ini memanfaatkan media pembelajaran berbasis teknologi informasi dan komunikasi (TIK) secara maksimal, walaupun sebenarnya terdapat sarana prasarana di sekolah yang menunjang penggunaan media pembelajaran berbasis TIK. Penyebab kurangnya guru memanfaatkan TIK dalam proses pembelajaran dikarenakan kurangnya pengalaman dalam menggunakan TIK, kurangnya waktu untuk mengintegrasikan TIK dalam pembelajaran, diperlukannya ahli TIK dalam proses pembelajaran dan diperlukannya pembiayaan yang lebih (Mumtaz, 2000 : 320).

\subsection{Penerapan media pembelajaran biologi di SMA A \\ Media pembelajaran yang sering} digunakan di SMA A adalah media cetak. Hal ini didukung oleh $95.2 \%$ siswa yang menyatakan demikian. Selain menggunakan media cetak, media lain yang digunakan adalah media visual tidak diroyeksikan, media visual diproyeksikan, dan media real.Pembelajaran akan berhasil jika disertai media yang tepat, pemakaian media yang tepat saat PBM berperan menciptakan stimulasi untuk siswa dan menjadikan media sebagai media belajar, selain membantu guru menyampaikan permasalahan dalam kajian tertentu (Emda, 2011: 160). Guru menerapkan media dengan menyesuaikan media sesuai dengan tujuan standar kompetensi yang akan dicapai. Materi biologi yang memerlukan media dalam proses penyampaiannya antara lain: materi bioteknologi. Guru akan terbatasi tindakannya dalam mengajar, berhubungan dengan apa yang seharusnya dia dapat lakukan di kelas jika kuarang menggunakan media pembelajaran (Mumtaz, 2000 : 336).

\subsection{Penerapan media pembelajaran biologi di SMA B \\ Media pembelajaran yang sering digunakan di SMA B adalah media}


cetak. Hal ini didukung oleh $84.3 \%$ siswa yang menyatakan demikian. Selain menggunakan media cetak, media lain yang digunakan adalah media diproyeksikan, media visual tidak diroyeksikan, media audio visual, dan media audio.Pembelajaran akan berhasil jika disertai media yang tepat, pemakaian media yang tepat saat PBM berperan menciptakan stimulasi untuk siswa dan menjadikan media sebagai media belajar, selain membantu guru menyampaikan permasalahan dalam kajian tertentu (Emda, 2011 : 160).

Guru di SMA B menyatakan sering menggunakan media pembelajaran yang ada di sekolah dalam proses belajar mengajar. Guru menerapkan media dengan menyesuaikan materi serta tujuan yang akan dicapai. Sebagian besar materi biologi memerlukan media pembelajaran. Materi biologi yang memerlukan media dalam proses pembelajaran adalah materi metabolisme, pertumbuhan tumbuhan, materi genetik, hereditas Mendel, evolusi, asal-usul kehidupan, reproduksi sel.

Sebanyak $84.3 \%$ siswa menyatakan, jika penerapan media pembelajaran oleh guru menjadikan siswa lebih aktif dalam pembelajaran. Sebanyak80.3 $\%$ penggunaanmedia pembelajaran menjadikan siswa lebih bersemangat untuk mengikuti pembelajaran biologi. Fungsi media pembelajaran yaitu : 1) memberikan kemudahan siswa dalam belajar, 2) mengubah pengalaman abstrak menjadi konkret, 3) proses belajar mengajar tidak membosankan, 4) meningkatkan minat, perhatian siswa pada proses belajar (Umar, 2013 : 133) mengenai.

\subsection{Penerapan \\ me dia pembelajaran biologi di SMA C}

Media pembelajaran yang sering digunakan di SMA C adalah media cetak. Selain menggunakan media cetak, media lain yang digunakan adalah media visual diproyeksikan, media audio visual, dan media audio, media teknologi mutakhir berbasis microprosessor.Pembelajaran akan berhasil jika disertai media yang tepat, pemakaian media yang tepat saat PBM berperan menciptakan stimulasi untuk siswa dan menjadikan media sebagai media belajar, selain membantu guru menyampaikan permasalahan dalam kajian tertentu (Emda, 2011 : 160).

Guru biologi di SMA C menerapkan media dengan membuat jenis media pembelajaran visual diam yang diproyeksikan, yaitu power point lalu memanfaatkan fasilitas yang berada di laboratorium. Berdasarkan observasi, fasilitas laboratorium jenis-jenis media pembelajaran SMA C yaitu media tradisional serta media yang berhubungan dengan teknologi informasi. Materi biologi kelas X yang memerlukan media dalam proses penyampaiannya antara lain: materi bab 1 - 6 yaitu bab ruang lingkup biologi, virus, Archaebacteria dan Eubacteria, protista, jamur, dan keanekaragaman hayati.Sedangkan materi biologi kelas XI yang memerlukan media dalam proses penyampaiannya antara lain: bab organisasi tingkat sel, organisasi tingkat jaringan, system gerak pada manusia, system peredaran darah pada manusia, kemudian bab system pencernaan makanan, system pernapasan, ekskresi, regulasi, reproduksi dan pertahanan tubuh. Materi biologi 
kelas XII yang memerlukan media dalam proses penyampaiannya antara lain: materi pertumbuhan dan perkembangan pada tumbuhan, metabolisme, genetika, pembelahan sel, prinsip hereditas, mutasi, evolusi, kecenderungan baru teori evolusi, bioteknologi. Guru biologi di SMA C bekerjasama dengan mahasiswa teknologi informatika Universitas swasta di Salatiga, yang mengembangkan media pembelajaran animasi terkait materi biologi sekolah menengah atas. Sebanyak $71.2 \%$ siswa menyatakan penerapan media menjadikan lebih aktif mengikuti pembelajaran.

\section{Faktor - faktor yang mempengaruhi penggunaan media pembelajaran biologi di Sekolah Menengah Atas Salatiga}

Menurut Priyayi (2016) guru merupakan salah satu penanggung jawab pembelajaran di sekolah. Guru memiliki peranan penting dalam pengelolaan faktor yang mempengaruhi belajar siswa. Konseptentang guru sebagai satusatunya sumber belajar, dapatd irubah menjadi belajar berbasis aneka sumber belajar. Media pembelajaran dapat berfungsi sebagai sumber belajar yang efektif. Guru perlu menggunakan mediayang dapat memaksimalkan proses pembelajaran di kelas. Pada prakteknya banyak faktor yang mempengaruhi penggunaan media pembelajaran .

Hasil penelitian menyatakan faktor-faktor yang mempengaruhi penggunaan media antara lain : Tingkat kesulitan materi menjadi faktor utama dalam guru menerapkan atau menggunakan media pembelajaran. Penggunan media dapat memudahkan siswa memahami materi. Penggunaan media tepat dan baik saat PBM mempunyai keuntungan bagi guru dan siswa salah satunya membantu kelancaran PBM dan bermanfaat untuk siswa dalam meningkatkan pengenalan, pemahaman terhadap materi (Emda, 2011 : 161). Media dapat menunjukan sesuatu yang konkrit. Hasil angket menunjukan rata-rata $76.8 \%$ siswa lebih mudah memahami materi pembelajaran apabila menggunakan media.

Tingkat penggunaan media juga dipengaruhi oleh tingkat ketersediaan media. Guru lebih mudah menggunakan media yang sudah tersedia di sekolah. Namun beberapa guru telah mengembangkan media pembelajaran sendiri. Ketrampilan dalam mengembangkan media diperoleh guru dari pelatihan maupun membuat secara mandiri. Hasil angket menujukan rata-rata $66.8 \%$ siswa lebih menyukai mata pelajaran biologi melalui penggunaan media pembelajaran. Media mempunyai kedudukan di sistem pembelajaran, umumnya yaitu alat mempermudah pemahaman, alat penghantar pesan, penguatan, pengganti guru dalam menjelaskan informasi lebih detail, cermat, menarik dan jelas (Kustandi dan Sutjipto, 2011: 19).

Tingkat kesiapan dalam KBM juga menjadi faktor yang mempengaruhi penggunaan media. Peran dan tugas guru sebagai penanggung jawab proses pembelajaran, perlu mempersiapkan hal-hal yang mendukung proses pembelajaran. Penggunaan media dipersiapkan untuk tingkat kemampuan siswa, memenuhi hal yang dibutuhkan dalam belajar, serta siswa bisa aktif berpartisipasi dalam kegiatan belajar mengajar (Arsyad, 2002: 81). Hasil angket menujukan 
rata-rata $66.1 \%$ siswa lebih aktif mengikuti pelajaran apabila menggunakan media pembelajaran dalam KBM. Selain kesiapan siswa, guru juga harus siap, dalam hal media yang akan digunakan, sistem mengoperasikan media, serta mengatur waktu penggunaan media dalam KBM. Guru harus memperhatikan dalam memilih media pembelajaran, diantaranya disesuaikan tujuan pembelajaran maupun kompetensi yang dicapai. Misalnya apabila kompetensi yang harus dicapai siswa berkaitan menghafal kata-kata dapat menggunakan media audio. Apabila kompetensi sifatnya memahami bacaan dapat menggunakan media cetak, jika kompetensi sifatnya motorik (aktivitas) pemakaian media atau video (Umar, 2013: 130).

Waktu pelaksanaan menjadi faktor guru menggunakan media pembelajaran, belum dimanfaatkannya media saat KBM antara lain karena waktu persiapan mengajar terbatas. Terbatasnya waktu juga dapat mengakibatkan tujuan pembelajaran tidak tercapai dan mengakibatkan pembelajaran menjadi kurang efektif. Hasil pengisian angket siswa menunjukan rata-rata $69.7 \%$ siswa lebih bersemangat mengikuti pembelajaran biologi jika menggunaakan media. Selain ketercapaian tujuan pembelajaran, yang harus dipertimbangkan adalah apakah media tersebut dapat menghemat waktu, tenaga dan biaya dengan tetap mempertimbangkan memiliki ketepatan informasi, memberikan siswa untuk berpartisipasi, memiliki kualitas yang baik dan dapat membangkitkan minat siswa (Heinich, dkk, 1982:34).
Jumlah siswa juga menjadi faktor pertimbangan dalam pemakaian media. Faktor penting dalam pemilihan media adalah pertimbangan jumlah siswa, jumlah siswa berpengaruh terhadap kenyamanan penggunaan media dan supaya pembelajaran bisa lebih interaktif (Caspi, 2005: 188). Media pembelajaran berperan sebagai sumber belajar yang dapat menghantarkan pesan dan mempermudah guru dalam menyampaikan materi sehingga proses pembelajaran lebih efektif (Yudasmara, 2015: 2).

\section{KESIMPULAN}

1. Jenis media pembelajaran yang paling lengkap adalah media pembelajaran yang terdapat di sekolah B, yaitu media cetak, visual,audiovisual, realia, permainan, elektronik atau computer. Sedangkan jenis media di sekolah A adalah media cetak, visual, realia, permainan. Jenis media di sekolah C adalah media cetak, visual, audio visual, realia, permainan, elektronik atau computer.

2. Jenis media yang paling tinggi penggunannya oleh guru biologi adalahjenis media pembelajaran berupa media pembelajaran cetak. Menurut guru, materi yang paling memerlukan media dalam penyampaiannya adalah materi bioteknologi, metabolisme, pertumbuhan tumbuhan, materi genetik, hereditas mendel, evolusi, asalusul kehidupan, reproduksi sel.

3. Faktor yang mempengaruhi penggunaan media tingkat kesulitan materi, tingkat ketersediaan media, tingkat 
kesiapan dalam KBM, waktu pelaksanaan dan jumlah siswa.

\section{SARAN}

1. Untuk guru

Dalam penyampaian materi pembelajaran, diperlukan rencana pelaksanaan pembelajaran salah satunya dengan mempersiapkan media pembelajaran.

2. Untuk sekolah

Jenis-jenis

media

pembelajaran di sekolah sebaiknya dimaksimalkan penggunaannya oleh guru. Guru perlu memperhatikan waktu pelaksanaan, tingkat kesulitan materi, ketersediaan sarana penunjang, dan kesiapan siswa dalam menerapkan media pembelajaran.

\section{DAFTAR RUJUKAN}

Arsyad, A. 2002. Media pembelajaran. Jakarta. PT Grafindo Persada.

Basri, H., S.S. Waspodo. 2013. Pengembangan Media Pembelajaran Berbasisis Computer pada Mata Pelajaran Ilmu Pengetahuan Alam untuk Meningkatkan MotivasiBelajar Siswa. Inovasi Pendidikan. 3(1): 35-44

Caspi, A. 2005. Instructional Media Choice: Factors Affecting the Preferences of Distance Education Coordinator. Israel. $\mathrm{Jl}$. Of Educational Multimedia and Hypermedia. (14) 2

Dzamarah dan Zain. 2006. Strategi Belajar Mengajar. Jakarta : Rineka Cipta.

Emda, A. 2011. Pemanfaatan Media Dalam Pembelajaran Biologi di Sekolah Aceh. Jurnal Ilmiah Didakita. (12) 1

Heinich, R., M. Molenda., dan J. D. Rusell. 1982. Instructional
Media and The New Technologies of Instruction. New York: John Wiley \& Sons

Indraswari, R. 2005. Miskonsepsi Tentang Terapung, Tenggelam dan Melayang pada Siswa SMU N 1 Salatiga. Skripsi tidak diterbitkan. Salatiga. Progam Studi Fisika Univesitas Kristen Satya Wacana: 14-17.

Kirkorian, H. L., Ellen A, Wartella., Daniel R, Anderson. 2008. Media and Young Children's Learning, The Future Of Children. (18) 1

Kustandi, C. dan B. Sutjipto. 2011. Media Pembelajaran Manual dan Digital.Bogor. Ghalia Indonesia

Mumtaz, S. 2000. Factors Affecting Teachers' Use of international and Communications Technology : A Review of Literature. Journal of Information Technology for Teacher Education. (9) 3

Naz, A.A. and A.A. Rafaqat. 2012. Use of Media For Effective Instruction its Importance Some Consideration. Pakistan. Journal of Elementary Education APublication of Deptt of Elementary Educational IER. 18 (1 -2): 35 $-40$

Priyayi, D. F. 2016. Analisis bahan Ajar Model Pembelajaran Alid (Accelerated Learning Included By Discovery) Pada Materi Jaringan Tumbuhan Kelas XI SMA N 7 Surakarta. Salatiga. Jurnal Pendidikan Sains. (4) 1

Sudjoko, 2001. Membantu Siswa Belajar IPA. Yogyakarta. FMIPA UNY 
Sugiyono. 2014. Metode Penelitian Pendidikan: Pendekatan Kuantitatif, Kualitatif dan $R \& D$. Bandung : Alfabeta

Tabor, S. W and Robert, P.M. 2013. Student Adoption and Development of Digital Learning media : Action Research and Recommended Practices. USA. Journal of Information Technology Education : research. (12)

Umar. 2013. Media Pendidikan : Peran dan Fungsinya dalam Pembelajaran. Jurnal Tarbawiyah. (10)

Yudasmara, G. A dan Purnami, D. 2015. Pengembangan Media Pembelajaran Interaktif Biologi untuk Meningkatkan Hasil Belajar Siswa SMP.Jurnal Pendidikan dan Pengajaran. 13 (48), 1-8. 